\title{
CULTURAL PARAPHRASE IN ROMAN RELIGION IN THE AGE OF AUGUSTUS. THE CASE OF THE SIBYL AND THE SIBYLLINE BOOKS
}

\begin{abstract}
Summary: In my paper I examine the use of Sibylline Books during Augustus' reign. I discuss the role of the Sibyl as well as the collection attributed to her in terms of cultural changes and cultural paraphrases. According to my opinion the prophetess had mainly cultural, not ritual significance. I argue for treating the interventions onto corpus of official Sibylline Books made by Augustus in the category of creating the new cultural identity for the inhabitants of the Empire.
\end{abstract}

Key words: Sibyl, libri Sibyllini, Roman religion, XVviri sacris faciundis, Roman priesthood, globalisation, cultural change

The Sibylline Books are a collection of the most famous Roman ritual texts. The history of their use in the Republican period has been briefly summarized in just a few words by John Scheid: "What you do is what you believe". ${ }^{1}$ Although Rome did not have an official oracle with functions resembling those of Delphi or Praeneste, the libri played a role similar to that of a state oracle. ${ }^{2}$ The Romans did not intend to ask the gods about the future of their country and of its society by employing the Sibylline Books, but they wanted to find a method to restore the pax deorum, which was a guarantee of the future state's success. ${ }^{3}$ The role of the books can be seen, however, mainly in terms of cultural changes that occurred in ancient Rome. A good example is the process by which these books were assigned to the Sibyl. This raises the question about the function of the books and the prophetess in the Roman cultural space. In this article, I will focus on the reign of Augustus because of these books' significant

\footnotetext{
${ }^{1}$ See SCHEID, J.: Quand faire, c'est croire. Paris 2005.

${ }^{2}$ Aul. Gel. 1. 19. 11: Ad eos quasi ad oraculum quindecemviri adeunt cum di immortales publice consultendi sunt. "To them the Fifteen resort whenever the immortal gods are to be consulted as to the welfare of the State." (trans. J. C. Rolfe).

${ }^{3}$ For this concept, see MADEJSKI, P.: Pax deorum? In Terra, mare et homines II. Studies in memory of Professor Tadeusz Łoposzko. Eds. H. KOWALSKI - P. MADEJSKI. Lublin 2010, 109-120.
} 
impact on the formation of the era. I would like to examine the following issues: was the Sibyl actually present in the ritual sphere and in civic religion? Or should we recognize her as a symbol of the globalization of culture and religion, and an important part of culture as a system? The next question is about the role Augustus played in the re-establishment or replacement of the Books. ${ }^{4}$ In my opinion, the affiliation of the Books to the Sibyl was a crucial factor in the globalization of Roman society and in Augustus' symbolic language.

The account of the acquisition of the oracular collection by king Tarquinius Superbus is well-known, and I suppose that there is no need to repeat it here. ${ }^{5}$ It is quite a typical aetiological myth, and despite the preserved accounts, it has mainly survived in only one version. The differences are minor and without great importance. ${ }^{6}$ It is obvious that those stories drew information from just one source. Contemporary historiography, without hesitation, uses the narrative of Lactantius and recognizes Varro as the author of the primary version. Jesse Keskiaho has recently published a brilliant resume of the story and its history in the study of historiography. ${ }^{7}$ The old woman who brought the books to Tarquinius was identified as the Sibyl. In Varro's story, she functions as Amalthea (or Herophile or Demophile) ${ }^{8}$ from Cumae, and is mentioned in the context of enlisting other prophetesses. Although the ancients mainly recognized the old woman as the Sibyl, the acceptance of the affiliation was rather problematic. Cumae ultimately came into an ideological "market" as the result of Augustus' propaganda, but not as a ritual reality. It should be noted that in $78 \mathrm{BC}$, when the Sibylline Books had been burnt during the fire in $83 \mathrm{BC}$ on the Capitol, a special commission established for dealing with these books' reconstruction did not go to Cumae. It focused its attention on the shore of Asia Minor, especially on Erythrae, and the Italian colonies, which are mentioned by Dionysius of Halicarnassus but without mentioning any cities by name. Eric Orlin writes that this fact meant that the Romans had recognized those cities as members of the Roman community. ${ }^{9}$ The omission of Cumae clearly shows that from a ritualistic point of view, this place never plays an important role in official Roman religion. I agree with scholars who think that the Romans knew

${ }^{4}$ In this text I develop some of my ideas first published in GiLlmEISTER, A.: Sibyl in Republican Rome - Literary Construction or Ritual Reality? In MusiAŁ, D. (ed.): Society and Religions. Studies in Greek and Roman History. Vol. 3. Torun 2010, 9-26. In that paper one can find full bibliography of the subject. Here I used some paragraphs from this text.

${ }^{5}$ Varro, Ant. rer. div. frg. 56a Cardauns (= Lact. Div. Inst. 1. 6. 10-11); Dion. Hal. 4. 62; Plin. NH 13. 88; Aul. Gel. 1. 19. 1-9; Solin. 2. 16-18; Serv. ad Aen. 6. 72; Tzetzes, Lyc. Alex. 1279.

${ }^{6}$ KeSKIAHO, J.: Re-visiting the Libri Sibyllini: Some Remarks on Their Nature in Roman Legend and Experience. In KAJAVA, M. (ed.): Studies in Ancient Oracles and Divination. Roma 2013, 145-172, here 150; BERNEDER, H.: Magna Mater Kult und Sibyllinen. Kulttransfer und annalistische Geschichtsfiktion. Innsbruck 2004, 13.

${ }^{7}$ KeSKIAHO (n. 6) 146-150. Discussion about libri, see also SANTI, C.: Sacra facere. Aspetti della prassi ritualistica divinatoria nel mondo romano. Roma 2008, 103-112; GILLMEISTER, A.: Strażicy ksiag sybillińskich: collegium viri sacris faciundis w rzymskiej religii publicznej [The Guardians of Sibylline Books]. Zielona Góra 2009, 23-26.

${ }^{8}$ About names of Sibyl: Tib. 2. 5. 65-70. Cf. MilLER, J. F.: Apollo, Augustus, and the Poets. Cambridge 2009, 142-143.

${ }_{9}^{9}$ ORLIN, E.: Foreign Cults in Rome. Creating a Roman Empire. Oxford 2010, 203; cf. SANTANGELO, F.: Divination, Prediction and the End of the Roman Republic. Cambridge 2013, 136. 
that they could not find there what they were looking for there - that is, the prophecies of the Sibyl. ${ }^{10}$

What, however, can be said about the Sibyllic affiliation of the Capitoline collection? In his narrative, Livy does not include the myth of the acquisition of the books. This seems bizarre, especially in the light of his extreme precision in registering all the signs of gods' benevolence as well as malevolence towards the Romans. What is more, in his narrative the Roman historian uses the expression libri Sibyllini only seven times, which is not frequent. He mentions the books nineteen times without adding any adjectives, and three times as fatales. ${ }^{11}$

What does this mean? First of all, it shows that the adjective "sibylline" was added late, which in turn implies its antiquarian origin. ${ }^{12}$ I would like to draw attention to the fact that, every time we identify the pontifical annals as Livy's source of information, we come across the term libri. In addition, libros adire iussi, which was probably the oldest and the most frequently used formula in reference to consulting the books, stands without any additional description. ${ }^{13}$ Secondly, in my opinion, the fact that the myth was omitted should be considered in the context of the realm of Augustus' propaganda; for many various reasons, identifying the state prophecies with a cultural symbol that was recognized in most parts of the Empire was in Augustus' interest. Livy, who was considered to be a closeted Republican, could not like the fact that Augustus took control over the books which contained fata et remedia and moved them to a private temple. Perhaps the historian wanted to remind his readers about the earlier role of the libri and their proper place in the political and religious life of Rome. ${ }^{14}$ On the other hand, this picture of Livy, painted more than half a century ago by Sir Ronald Syme, is as powerful as it is misleading, and we should be rather cautious here. Livy was also beneficial to Augustus in his attempts to reshape the Romans' minds. Moreover, we can assume that, in the times when Livy was writing his account, two traditions were still upheld. One of them rejected the Sibylline affiliation of the collection which undoubtedly already had an "Apollonic" character, in opposition to a previous one which was subject to Jove, due to its content and the place where it was kept (e.g. carmina Marciana with a direct reference to Jove). ${ }^{15}$ At the same time, it is worth pointing out that the Sibyl is not mentioned in the epigraphic protocol of the Secular Games of 17 BC. It shows that the rites were performed during the Secular Games without the authority of the prophetess, and provides us with excellent evidence that the Sibyl did not function in the sphere of cult but merely in

\footnotetext{
${ }^{10}$ Poucet, J.: Les Tarquins, les Livres Sibyllins et la Sibylle de Cume: entre tradition, histoire et imaginaire. FEC 16 (2008), http://bcs.fltr.ucl.ac.be/FE/16/SibylleCumes.htm [access on-line: 15.11.2014].

${ }^{11}$ BLOCH, R.: Origines etrusques des livres Sibyllins. In Mélanges de philologie, de littérature et d'histoire anciennes offerts à Alfred Ernout. Paris 1940, 21-28, here 24; KESKIAHO (n. 6) 156.

${ }^{12}$ Cf. BeRNEDER (n. 6) 20-26.

${ }^{13}$ E.g. Liv. 21. 62. 6; 22. 36. 6; 40. 20. 2. Full lists of references: GiLLMEISTER: Strażnicy (n. 7) $77-79$.

${ }^{14}$ About Livy's attitude towards Augustus, see classical studium of SYME, R.: Livy and Augustus. HSCPh 64 (1959) 27-87. See also METTE, H. J.: Livius und Augustus. Gymnasium 68 (1961) 269-285; PETERSEN, H.: Livy and Augustus. TAPA 92 (1961) 440-452.

${ }^{15}$ Fevrier, C.: De l'usage des Livres: le décemvir, prêtre ou vates? Latomus 61 (2002) 821-841, here $828-829$.
} 
the sphere of culture. I also think, perhaps a little paradoxically, that this view may be strengthened by the context in which the prophetess appears in Horace's Carmen Saeculare. She is presented as the patroness of oracles (Sibyllini versus, line 5), who contributed to the creation of the poetic piece which was the 'reminder' of the obligation to celebrate this festival. ${ }^{16}$ In my opinion, this reference has rhetorical significance and shows the popular affiliation of the state collection, but not the real presence of the Greek prophetess in the Roman ritual space during the reign of Augustus. I mean that from ritual point of view adjective 'sibyllini' which sometimes replaces 'rituales' did not change the sense of collection from Capitol and later Palatine. ${ }^{17}$

Was the Augustan Sybil something more than a cultural phenomenon? I think not. It is worth noticing that in Cumae, which was considered to be her seat, there was no sacral building that could be regarded as an oracle of Sibyl. Jean Poucet in his brilliant study about the Sibyllic tradition in Cumae stated that the presence of the Cumean Sibyl was a kind of "medial phenomenon" or, to be more precise, a literary one. ${ }^{18}$ Gabriela Vanotti, in her article on literary sources about presumed oracular rites in Cumae, commented on one of the hypotheses of a fellow historian who researched this matter by writing that it needs "un atto di fede". ${ }^{19}$ In my opinion, it is rather hard to avoid the impression that this is exactly what is necessary to accept the presence of the Sibylline mantic in Cumae. ${ }^{20}$ What is more, we do not have any sources from the Republican period that say anything about consulting such an oracle. Furthermore, one should remember that in Rome, Sybil was identified entirely as the prophetess of Apollo, a fact which is important to consider when reflecting on her role in Rome of the Republic and the early Empire. It is particularly interesting as even a superficial reading of the preserved sources allows us to conclude that in the Republican period the oracular aspect of the Roman Apollo was not really important. ${ }^{21} \mathrm{He}$ was worshipped mainly as the god of healing and also, since the Second Punic War, of victory. It can be considered that Apollo was only a relatively minor deity in the Republic, and only in the last century of the Republic began to take on greater significance. It is quite visible that in the time of crisis of Republic which began with the Gracchan perion, there was accented another aspect of this deity. Apollo became god of liberty who inspired antityrannic actions. ${ }^{22}$ Process of giving to Apollo greater significance was accelerated during the reign of Augustus, especially after the construction of the Pala-

\footnotetext{
${ }^{16}$ PutnAm, M. C. J.: Horace's Carmen Saeculare. Ritual Magic and the Poet's Art. New Haven London 2000, 55, 91.

${ }^{17}$ Gillmeister, A.: The Role of the Viri Sacris Faciundis College in Roman Public Religion. In Musiat, D. (ed.): Society and Religions. Studies in Greek and Roman History. Vol. 2. Torun 2007, 55-72, here 70 .

${ }^{18}$ POUCET (n. 10). On the literary mention about oracular practises in Cume, cf. VANOTTI, G.: Riti oracolari a Cuma nella tradizione letteraria di IV e III secolo a.C. In CHIRASSI COLOMBO, I. - SEPPILLI, T. (ed.): Sibille e linguaggi oracolari. Mito - Storia - Tradizione. Atti del convegno, Macerata Norcia, settembre 1994 [Ichnia 3]. Pisa-Roma 1998, 263-276.

${ }^{19}$ VANOTTI (n. 18) 272.

${ }^{20}$ GILLMEISTER: Strażnicy (n. 7) 13-14.

${ }^{21}$ The issue of the relation between Apollo and libri is widely discussed by SANTI (n. 7) 133-178.

${ }^{22}$ Cf. Mastrocinque, A.: La cacciata di Tarquinio il Superbo. Tradizione romana e letteratura greca (prima parte). Athenaeum LXI (1983) 474-480.
} 
tine temple of Apollo, which in some aspects should join the Capitoline as a second major center of Roman civil religion. An example of this was to put in the books attributed to the Sibyl and celebration on the Palatine of a substantial part of the ludi saeculares in $17 \mathrm{BC}$. In any case, the prophetic aspect was hardly exhibited in the Republic. Augustus perhaps initially used Apollo as a metaphor for healing the state after the dangerous times of the civil wars. ${ }^{23}$ How can we otherwise explain that during the entire period when the original collection was being kept at the Capitol the supplicants were still sent to Delphi and in a few cases they brought back exactly the same advice as those drawn from the books? ${ }^{24}$

We can also add that while Apollo emerged as a predominant deity in Cumae around $410 \mathrm{BC}$, the Books had already appeared in Rome almost a century before. ${ }^{25}$ Before the 5th century BC, one of the primary deity was Hera. Scholars learned of her oracular role here after the discovery of a bronze disc with a Greek inscription (dating on 7th-6th BC). This disc was interpreted as evidence of oracular activity on behalf of Hera. However, there is a strong possibility that the inscription had another meaning. It could simply be the way of announcing the prohibition of supplications in the sacred area. ${ }^{26}$

In the Latin written sources, Sibyl appeared in the 2nd century BC in Plautus' Pseudolus, dated to $191,{ }^{27}$ and in the preserved fragment of Calpurnius Piso's Annales, dated to the 2 nd half of the 2 nd century BC. ${ }^{28}$ It would be difficult not to mention here that the oldest Hellenistic and Judeo-Hellenistic oracula Sibyllina come from the 2nd century BC. ${ }^{29} \mathrm{We}$ should also point out that it was in the 3rd and the 2 nd centuries that the Romans created a new category in their religion: ritus Graecus. Similar to the Sibylline myth, it was supposed to cement the new cultural community of the Romans and the Greeks and show the depth of the cultural and intellectual ties between the Roman and the Greek worlds. ${ }^{30}$

${ }^{23}$ MiLLER (n. 8) 28-30.

${ }^{24}$ About the Republican envoys to Delphi, see PARKe, H. W. - Wormell, D. E. W.: The Delphic Oracle. Oxford 1956, 265-282; Relation between Romans and Delphi in various periods, see POUILLOUX, J.: D’Archiloque a Plutarque. Littérature et Réalité. Lyon-Paris 1996, 281-299, 338-344, 374-381.

${ }^{25}$ First consultation of the Books are dating on 504 (Plut. Pupl. 21. 1-3), 496 (Dion. Hal. 6. 17. 2-3) and 461 (Liv. 3. 10. 5-7; Dion. Hal. 10. 2. 3-4; Val. Max. 1. 6. 5).

${ }^{26}$ KAJAVA, M.: "Hera non permette che...". Ancora sul discetto bronzeo di Cuma. In CHIOFFI, L. (ed.): Il Mediterraneo e la storia. Epigrafia e archeologia in Campania: letture storiche. Istituto Italiano per gli Studi Filosofici, Napoli, 4-5 dicembre 2008. Naples 2010, 7-22; BUCHHOLZ, L.: Identifying the oracular sortes of Italy. In KAJAVA, M. (ed.): Studies in Ancient Oracles and Divination [Acta Instituti Romani Finlandiae 40]. Rome 2013, 111-144, here 126-129.

${ }^{27}$ Plaut. Pseud. 1. 25: Has quidem pol credo nisi Sibulla legerit. JoHnston, P. A.: Juno’s Anger and the Sibyl at Cumae. Vergilius 44 (1998) 13-23; GUARDUCCI, M.: Un antichissimo responso dell'oracolo di Cuma. BCAC 72 (1946-1948) 129-141.

${ }^{28}$ Calp. Pis. fr. 2-3 ed. M. Chassignet.

${ }^{29}$ RADKE, G.: Zur Entwicklung der Gottesvorstellung und der Gottesverehrung in Rom. Darmstadt 1987, 60; Cf. HoffmanN, W.: Wandel und Herkunft der Sibyllinischen Bücher in Rom. Leipzig 1933, 14-15; Collins, J. J.: The Development of the Sibylline Tradition. ANRW II, Berlin - New York 1986, 421-459, here 431; Collins, J. J.: Seers, Sibyls and Sages in Hellenistic-Roman Judaism. Leiden New York - Köln 1997, 186 (dated to the second half of the 2nd century BC).

${ }^{30}$ Cf. SCHEID, J.: Graeco ritu: a Typically Roman way of Honourng the Gods. HSCPh 97 (1995) 15-34, here 29-31; SANTANGELO (n. 9) 128. 
On the basis of these references (at least until the 1st half of the 1st century BC), it is difficult to claim that the generic Roman Sibylline mantic functioned in the official religious life of the Romans. One can notice, however, the increasing influence of the Judeo-Hellenistic oracles called oracula Sibyllina in the formation of certain elements of the religiousness common for the inhabitants of the Empire. According to Giulia Sfameni Gasparro, at the turn of the 3rd and the 2nd century BC the mutual openness of the Jews and the Greeks under the reigns of the Ptolemies allowed the creation of new oracula which responded to the new, common challenges. ${ }^{31}$ We encounter a similar situation in the time of Augustus, who used oracles popular during the time of the civil wars - e.g. the one(s) about the return of the Golden Age - to create yet another element that contributed to the formation of the identity of the Empire. The myth of Golden Age was very popular in the Graeco-Roman world. It was first mentioned in the Works and Days by Hesiod (vv. 42-46). Roman poets adopted the myth and the term aurea saecula or aurea aetas. ${ }^{32}$ Augustus used it to mark the beginning of a new Rome. I think we can partially put those political and rhetorical actions into the Messianic landscape represented by the oracula Sibyllina. However, the question on how much influence those Judeo-Hellenistic prophecies had on the official collection has to remain, in my opinion, without a definite answer. It should be noted, however, that their potential impact on Horace and Virgil, who shaped Augustan propaganda by paraphrasing Greek culture in Rome, is quite possible. ${ }^{33}$ In this context we should recall the "Third Sibylline Oracle". The prophecy was mentioned by Alexander Polyhistor, although the oracle could be quite older. ${ }^{34}$ Of course, it is hard to say to what extent these Judeo-Hellenistc prophecies influenced Roman writers. Jan Bremmer stated that: "It is hardly surprising that in the bloody first century BC, Romans looked for prophecies, and the Jewish Sibyllines will have been fairly well known at the time." ${ }^{, 35}$ It is likely in official Roman collection were those kind of prophecies. It's true that a lot of them had anti-Roman overtone, but we have to remember two important things. In 2nd century BC the Seleucidian empire was, not Rome, a main enemy of Jewish. ${ }^{36}$ Second, Capitoline collection was carefully edited and it is unlikely that pure anti-Roman prophecies were there.

${ }^{31}$ SFAMENI GASPARRO, G.: Oracoli, profeti, sibille. Rivelazione e salvezza nel mondo antico. Roma 2002, 78. About oracula Sibyllina see also UsHER, M. D.: Teste Galba cum Sibylla: Oracles, Octavia, and the East. CPh 108 (2013) 21-40; LightFoOT, J. L.: The Sibylline Oracles with Introduction, Translation, and Commentary on the First and Second Books. Oxford 2007, esp. 3-93, 153-218; BROCCA, N.: Lattanzio, Agostino e la Sibylla maga. Roma 2011.

${ }^{32}$ E.g. Hor. Ep. 16; Hor. Odes 4. 2. 39-40; Verg. Ecl. 4. 6-10; Verg. Georg. 2. 458-540; Verg. Aen. 6. 791-793. The literature of the subject is enormous, see e.g. BALDRY, H. C.: Who Invented the Golden Age? Classical Quarterly 2 (1952) 83-92; Johnston, P.: Vergil's Agricultural Golden Age. A Study of the Georgics. Leiden 1980; WallaCE-HAdRILl, A.: The Golden Age and Sin in Augustan Ideology. Past and Present 95 (1982) 19-36; BARKER, D.: 'The Golden Age is proclaimed'? The carmen saeculare and the Renascence of the Golden Race. Classical Quarterly 46 (1996) 434-446.

${ }^{33}$ USHER (n. 31) 22.

${ }^{34}$ LIGHTFOOT (31) 95-96.

${ }^{35}$ Bremmer, J. N.: Virgil and Jewish Literature. Vergilius 59 (2013) 157-164, here 160. Cf. WALlACE-HADRILL (n. 31) 21: "It should now be accepted that Virgil had indirect access to Jewishoriental Messianic ideas through hellenistic Jewish 'Sibylline oracles' (...)".

${ }^{36}$ NIKIPROWETZKY, 199; contra MASTROCINQUE, 172-173, who put a stress on an anti-Roman character but he also treated circulation of the prophecies as an example "una temperie culturale diffusa in tutto il mondo ellenistico". 
In the contemporary literature on the subject we come across a rather common mistake of identifying libri with oracula Sibyllina, which is simply the confusion of these two notions. ${ }^{37}$ First of all, we should highlight the main difference between those two modes of divinations. The state books contained fata et remedia and were related to pax deorum. It is worthwhile to mention here that these fata can be interpreted not as oracles, but as the reason why the books were consulted. ${ }^{38}$ In the Republican period, additional elements were gradually added to fata, but only after it had been verified that they were in accordance with mos maiorum - the basic category of the Roman perception of gods and their relations with people. ${ }^{39}$ The new collection created after the fire on the Capitol had to have a different quality. Not only was its content changed, probably into more homogeneous one, but it is also highly probable that in this case we witness changes in the notion of the mos maiorum. Those changes were to redefine the term so it could meet the challenges of the new era. The Hellenistic prophetess Sibyl, a figure who was multidimensional, multi-characteristic and recognizable in the whole oikoumene, was a perfect match to be used for this purpose. Without doubt, the new collection contained a prophetic element and differed in every way from the original collection, which quickly took on the nature of the palimpsest through inclusion of the other texts, such as the prophecy of Vegoia or carmina Marciana. The new collection is the result of the decisions made by the special Senatorial committee. The predictions came from three sources, according to Dionysius of Halicarnassus: one part obtained in Erythrea, another in the Italic colonies, and others copied from private collections. I think the new books could be seen as a kind of "paraphrase" of the previous collection. Romans, faced with the choice between authenticity and currency, without doubt had chosen authenticity. They assumed that the new collection expressed the old spirit. According to John Scheid some fragments of old libri could be preserved in the responsa send by Senate to the colonies, and although were re-used by the committee, it was to little excerptions to recreated original. ${ }^{41}$

However, was the new collection dependent in any way on the increasingly popular oracula Sibyllina? Most likely, yes. Perhaps it was the only time when semantic scope of Roman libri was close or even partly covered with the oracula? Nevertheless, it is difficult to answer this question because of a very simple reason: we know the content of the Roman books only from secondary sources. The main difference in both forms (that is, the libri and oracula) of the Sibylline divination was their character. As Gulia Sfameni Gasparro has remarked, the Greek prophetesses did not need any special means to fulfil their mission and functioned outside the secular structures, and

${ }^{37}$ See e. g. MONACA, M.: La Sibilla a Roma. I libri sibyllini fra religione e politica. Cosenza 2005, 87-93, 230-231.

${ }^{38}$ RADKE (n. 29) 65.

${ }^{39}$ See VERNOLE, V. E.: Mos maiourm: problemi storico-religiosi. SMSR 68 (2002) 265-274.

${ }^{40}$ GuITTARD, CH.: Carmen et prophéties à Rome. Turnhout 2007, 275-287 (carmina Marciana) and 289-305 (the prophecy of Vegoia).

${ }^{41}$ Dion. Hal. 4. 62. 5-6; other sources: Fen. Ann. fr. 18 apud Lact. Div. Inst. 1. 6. 14. Cf. PARKE, H. W.: Sibyls and Sibylline Prophecy in Classical Antiquity. London 1988, 138; GILLMEISTER: Strażnicy (n. 7) 27-30; KESKiAHO (n. 6) 166-167. Cf. SCHEID, J.: Les livres Sibyllins et les archives des quindécemvirs. In MOATTI, C. (ed.): La mémoire perdue: recherches sur l'administration romaine. Rome 1998, 11-26, here 22-23. 
the act of prophecy depended purely on a god's will. ${ }^{42}$ In Rome, however, the priests were always standing between gods and mortals; therefore, the case of the sort of divination called "Sibylline" being entirely subordinated to the state is not an exception. Authority over any form of religious practice is the responsibility of the Senate - as on other matters that are important for the good operation of the State. ${ }^{43}$ Arnaldo Momigliano also highlights this fact and stresses the Roman specifics of the manner in which the prophecies ascribed to the Sibyl were dealt with. ${ }^{44}$ For me, however, most important is another difference which I have already mentioned: libri had an official and civic character, they were supposed to help maintain peace with gods. Oracula have an eschatological character because they are based on revelations uttered by the prophetess partly inspired by the god's frenzy. This is also how Virgil presented the Sibyl's act of making prophecies. ${ }^{45}$ The picture is very colourful and very different from the "traditional" point of view represented by Cicero. ${ }^{46}$ This Roman politician, writer and also priest (he was an augur) saw a lack of frenzy - furor divinationis - as the main difference between the official collection and other prophecies that circulated under the Sibyl's name. However, there is also one more very important divergence. Apart from the fact that the oracle was spoken in a state of madness, it was not presented in the written form, unlike the libri. ${ }^{47}$ In his paraphrases of Greek oracular practices, ${ }^{48}$ Virgil had ultimately created a "Roman" Sibyl. ${ }^{49}$ This Sibyl was in accordance with the religious tendencies of the first Princeps, by the ultimate association with the official oracular collection and the members of sacris faciundis college, with Apollo. It is worth noting that the Latin commentators did not always believe that Virgil was a consistent supporter of the Sibyl's Cumean origin. According to Probus, the phrase $\mathrm{Cu}$ maeum carmen coming from Eclogue 4 (v. 4) refers to Hesiod, whose family came from Cumae (Aeolian Cyme) and his theory of the centuries. ${ }^{50}$ It should provide us with another proof that the Sibyl was regarded in a framework of a cultural code readable for the inhabitants of the Augustan empire.

However, in Roman religious reality, these books were used solely in the situation of breaking the pax deorum. The Romans had a well-developed civic "theology".

${ }^{42}$ SFAMENi GASPARRO (n. 31) 85.

${ }^{43}$ ORLIN, E.: Augustan Religion and the Reshaping of Roman Memory. Arethusa 40 (2007) 7392, 77. ANDO, C.: The Matter of the Gods. Religion and the Roman Empire. Berkeley - Los Angeles London 2008, 124-128.

${ }^{44}$ Momigliano, A.: Dalla Sibilla pagana alla Sibilla cristiana. Profezia come storia delle religione. Annali della Scuola Normale Superiore di Pisa 17 (1987) 407-428, here 409.

${ }^{45}$ Verg. Aen. 6. 77-101. About Sibyl in Aeneis: MILLER (n. 8) 133-149 with the fully bibliographical references. See also SAGgIORNO, A.: La Sibylla cumana. Un personaggio virgiliano tra mito e storia. SMSR 62 (1996) 481-490.

${ }^{46}$ Cic. de div. 2. 54.

${ }^{47}$ Verg. Aen. 6, 74-75; SANTANGelo (n. 9) 231.

${ }^{48}$ The Delphic Pythia, also a prophetess of Apollo, was sometimes described as a wild person who make an act of prophecies in frenzy, cf. BowDEn, H.: Classical Athens and the Delphic Oracle. Divination and Democracy. Cambridge 2005, 21. About the language of the prophecies in Italy, see POCCETTI, P.: Fata canit foliisque notas et nomina mandat. Scrittura e forme oracoli nell'Italia antica. In CHIRASSICOLOMBO-SEPPILli (n. 18) 75-105, here 86-89.

${ }^{49}$ Berneder (n. 6) 14-16. Cf. SATtERFIELD, S.: Rome's Own Sibyl. The Sibylline Books in the Roman Republic and Early Empire. Princeton 2008 (unpublished PhD dissertation).

${ }^{50}$ USHER (n. 31) 27. 
Pax deorum, the state of equilibrium between the gods and the people, played the central role in their approach to the gods. This is why the Senate and the priests carefully followed all the signs of the gods' malevolence towards Romans. Prodigia were the most important signs of the gods' wrath and libri were used when omens were extremely dangerous and, in addition, the social crisis occurred. ${ }^{51}$ In this context, I would like to quote the opinion of Jesse Keskiaho, who wrote that "the attention to prodigies and their expiation seems to have been characteristic of how the Romans viewed their relationship with their gods. One may suppose that whatever books of whatever origin (Greek, Etruscan or purely Roman) the Roman used, they used them in a way consonant with their own religious culture. Rather than what the books were, their use may simply tell us how the Romans used them - or even, how the Romans writing their history wished to perceive the central religious concerns of early Romans". ${ }^{52}$ This statement is very true and shows the originality of the Republican Books and, indirectly, the shift in religious paradigm at the turn of era.

During the period of the Empire, unlike highly popular oracula Sibyllina, the libri stored on the Palatine were rarely consulted and practically did not play any significant role in the religious life of the Romans. In the years AD 64-241 no consultations of the Sibylline Books were noted, with the exception of unconfirmed (but logical) consultations in connection with the celebrations of Secular Games held under Claudius, Domitian and Septimius Severus. ${ }^{53}$ It is possible that, in the popular perception, both forms of divination were perceived as one and the same.

Even if the new collection consisted of oracula, Augustus attempted to give it a more 'Roman' meaning in terms of civic, "traditional" content and tried to preserve its integrity. Augustus revised the books twice. The first time was in $18 \mathrm{BC}$, before the celebration of the ludi saeculares, which is mentioned by Cassius Dio. ${ }^{54}$ The historian claims that the Princeps ordered the rewriting of the books under the pretext of their bad shape:

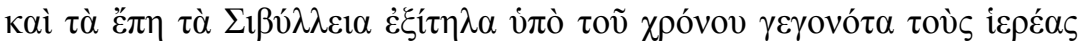

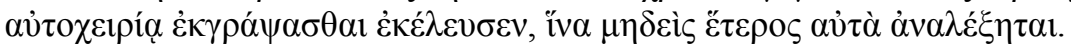

$[\ldots]$ and the Sibylline verses, which has become through lapse of time, should be copied off by the priests with their own hands, in order that no one else might read them. (trans. E. Cary).

The copying was supposed to be done by the members of the collegium, who were to handle them by wearing gloves. The fact that this work was assigned to quindecemviri alone is important. Firstly, Augustus decided to entrust the content of the books

${ }^{51}$ Dion. Hal. 4. 62. 5 used the term stasis and Val. Max. 1. 1. 1 tumultus when they described the reasons for consultation. In fact only the consultations connected with ludi saeculares are not directly connected with social crisis.

${ }_{53}^{52}$ KeSKiAHO (n. 6) 156.

${ }^{53}$ GILLMEISTER: The Role (n. 17) 71

${ }^{54}$ Dio 54. 17. 2; J. GAGÉ (Apollon romain. Essai sur le culte d'Apollon et le développement $d u$ 'ritus graecus' à Rome des origines à Auguste. Rome 1955, 570) writes about one inspection, which he dates to the period before $17 \mathrm{BC}$. 
to the people who belonged to his closest circle. Secondly, by using one of the collegia amplissima the Princeps showed to the public his attachment to ancestral religion. Augustus ordered this act as a magister collegium, and on this occasion, supposedly by chance, regulations were discovered which allowed for the celebration of the ludi saeculares to take place a year later, in $17 \mathrm{BC}$, in accordance with "the ancestral tradition". ${ }^{55}$ Despite this assurance, Augustus offered the new rite and the new custom for the ancient festival. ${ }^{56}$ In 12 BC Augustus, who was already a pontifex maximus, yet again amended the books by disposing of the potentially disloyal sections. According to Suetonius' narrative, the Princeps ordered that all the Latin and Greek prophetic manuscripts be gathered, and all but the Sibylline collection, of which he nonetheless selected only certain fragments, be burnt. ${ }^{57}$

It clearly changed the attitude towards the prodigia and libri during the Augustan era. Dionysius wrote about the decrease of the role of prodigia and the Sibylline Books under Augustus: ${ }^{.8}$

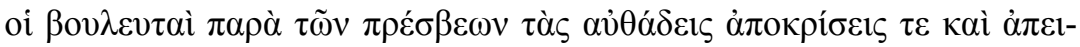

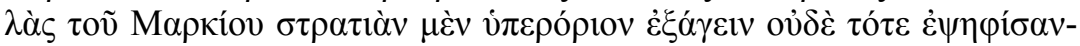

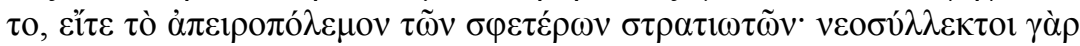

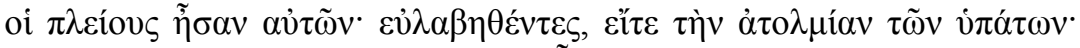

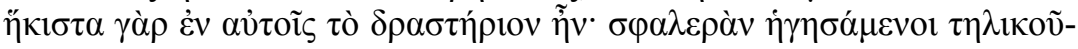

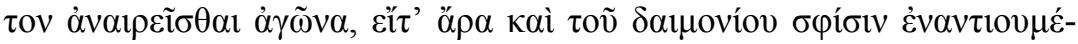

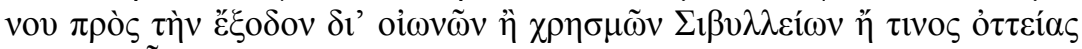

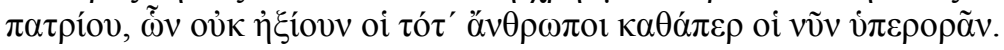

The senators, upon being informed by the envoys of the haughty answer and threats of Marcius, did not even then vote to send out an expeditionary force, either because they feared the inexperience of their troops, most of whom were new recruits or because they regarded the timidity of the consuls - there was indeed no boldness for action in them at all - as a serious risk in undertaking so great a struggle, or perhaps too because Heaven opposed their expedition by means of auspices, Sibylline oracles,

${ }^{55}$ BeArd, M. - North, J. - Price, S.: Religions of Rome. Cambridge 1998, 205; RidLEy, R. T.: The Absent Pontifex Maximus. Historia 54 (2005) 275-300, here 285, 290.

${ }_{57}^{56}$ ORLIN: Augustan Religion (n. 42) 78.

${ }^{57}$ Suet. Aug. 31. 1: Postquam vero pontificatum maximum, quem numquam vivo Lepido auferre sustinuerat, mortuo demum suscepit, quidquid fatidicorum librorum Graeci Latinique generis nullis vel parum idoneis auctoribus vulgo ferebatur, supra duo milia contracta undique cremavit ac solos retinuit Sibyllinos, hos quoque dilectu habito; condiditque duobus forulis auratis sub Palatini Apollinis basi. "After the death of Lepidus, when he finaly took on the office of pontifex maximus, which he had never taken upon himself to remove from Lepidus while he was alive, he collected whatever prophetic works of Greek and Latin origin were in circulation with no author's name or authors of insufficient worth, burning more than two thousand of them, and kept only those written by the Sibyl, making a selection even from these. He deposited them in two golden cases under the pedestal of Apollo Palatinus." (trans. D. Wardle). SANTANGELO (n. 9) 137, rightly stress that Augustus' intervention onto official corpus gave him "a formidable political weapon, which still had much clout in the complex landscape of late Republican religious life".

${ }^{58}$ Dion. Hal. 8. 37. 3. Cf. ENGELS, D.: Dionysius of Halicarnassus on Roman Religion, Divination and Prodigies. In Deroux, C. (ed): Studies in Latin Literature and Roman History. Vol. 16. Bruxelles 2012, 160-161. 
or some traditional religious scruple - a warning which the men of that age did not think fit to neglect as do those of today. (trans. E. Cary).

Dionysius lived in Rome for many years and was able to observe a very clear shift in the way the books were used. ${ }^{59}$ Augustus personally ordered the purging of the collection from politically inconvenient - as we can suppose - verses and transferred it from the temple of Jupiter Optimus Maximus to the newly built private temple of Apollo which was constructed next to Augustus' palace. The reverse of an Augustan coin minted in Rome in 16 BC, the APOLLINI ACTIO type, shows the foruli in which the Sibylline Books were housed sub Palatini Apollinis basi, as Suetonius reports (Aug. 31. 1). ${ }^{60}$ The political role of the Roman state oracle had become minimal while at the very same moment the renaissance of the Sibyl in Roman culture had reached its zenith.

Thus, Augustus introduced the Sibyl into Roman culture and transformed her into a significant factor of the new, universal culture of his empire. As John F. Miller remarked, the concept of an Augustan imprint, that is, the term "Augustanism", is quite difficult to theorize. ${ }^{61}$ However, in order to understand better the meaning of this shift of the paradigm and its "paraphrase" we can use an anthropological approach to Roman religion and introduce the term "acculturation", which was the form of cultural diffusion that occurred when various cultural features were spread by appropriation. This appropriation can occur through space (from culture to culture) or structure (from one social group to another within the same society). Anthropologists claim that the forms of social structure and basic values are subject to acculturative changes. Acculturation is a swift process which happens during the lifetime of one or a few generations. This approach will allow us not to think about Roman culture and art as secondary, which occurs when we analyze them in relation to Greek models and not in their own historical environment. ${ }^{62}$ When writing about the process of acculturation in Rome, Paul Veyne states that, in many cases, even if the Romans were inspired by Greek models, they filled them with their own ideas. They were not, strictly speaking, translating one culture into another, but rather paraphrasing it. The French scholar also reminds us that acculturation, which in this case is considered by him to be almost a synonym of Hellenization, does not exclude the originality of the culture which is subject to the process nor the one that emerges as new. ${ }^{63}$

Does the case of the adaptation of the 'Augustan' Sibyl to the Roman cultural tradition represent the same process? Formulating firm opinions on the basis of definitions and terms invented to describe a different cultural situation is, to say the least, risky. However, one has to admit that they much better reflect the characteristic of

${ }^{59}$ Cf. MARTin, P. M.: La propagande augustéenne dans les Antiquités romaines de Denys d'Halicarnasse (livre I). REL 49 (1971) 162-179.

${ }^{60} R I C \mathrm{I}^{2}$, no. 365 . I would like to thank Victoria Győri for showing me this note.

${ }^{61}$ Miller (n. 8) 5. See also KenNedy, F. D.: 'Augustan' and 'Anti-Augustan'. Reflections on Terms of Reference. In Powell, A. (ed.): Roman Poetry and Propaganda in the Age of Augustus. London 1994, 26-58.

${ }^{62}$ MuSIAE, D.: Dionizos w Rzymie [Dionysus in Rome]. Kraków 2009, 32.

${ }^{63}$ VEYNE, P.: The Hellenization of Rome and the Question of Acculturations. Diogenes 27 (1979) 1-27, here 22-24. Cf. Morley, N.: Theories, Models and Concepts in Ancient History. London - New York 2004, 127-130. 
the changes experienced by Roman culture in the time of the Republic and the early Empire than the excessively overused term "Hellenization".

Perhaps we should use the term that can be applied much more widely: globalization. So far, its usage in reference to the Roman culture of the Imperial period has brought promising results. ${ }^{64}$ One way or another, redefinition of the collection stored on the Capitol and then moved to the Palatine should be considered precisely in terms of these categories - the change of the cultural and not the religious character. These changes started to occur at the turn of the $3 \mathrm{rd}$ and 2 nd centuries $\mathrm{BC}$, but reached their apogee at the turn of the eras; they had either an acculturation or global character, and they were the key elements of the process planned by Augustus, that is, the process of building the new cultural identity for the inhabitants of the Empire and shifting the meaning of the Roman religion from the religion of place (limited to Rome) to the more universal spread of an empire. ${ }^{65}$ All these changes led to the creation of a new cultural landscape in which the important role played by the Sybil was a simple way to expand the boundaries of Roman-ness.

On this subject, I put culture and religion in strong opposition. This approach is of course ahistorical when we consider pre-modern society, especially the Roman one. Presentation of the opposition, as well as the use of other terms, such as globalization or acculturation, is the obvious use of terms from today's arts in relation to contemporary cultural situations. They are similar to Max Weber's "Idealtypen". I think they are useful tools for an intellectual discipline with adequately better recognition of the past, or at least for suggesting a more nuanced picture of it. ${ }^{66}$ Claudia Santi has stated that is it is good to use the terms from one cultural reality to better understand another one. ${ }^{67}$ I hope that my methodological contradiction has helped to show more clearly the extraordinary role which Augustus assigned to the figure of Sibyl and the re-established libri Sibyllini.

\author{
Andrzej Gillmeister \\ Dept. of History \\ University of Zielona Góra \\ Poland \\ a.gillmeister@ih.uz.zgora.pl
}

${ }^{64}$ Cf. Hingley, R.: Globalizing Roman Culture. Unity, Diversity and Empire. London - New York 2005; WALlaCe-HadRILl, A.: Mutatio morum: the Idea of Cultural Revolution. In HABINEK, T. SCHIESARO, A. (ed.): The Roman Cultural Revolution. Cambridge 1997, 2-22; WALlaCE-HADRILL, A.: Rome's Cultural Revolution. Cambridge 2008, 3-38.

${ }^{65}$ About 'religion of place', see ORLIN (n. 9) 78-80; ORLIN, E.: Augustan Religion: from Locative to Utopian. BRODD, J. - REED, J. L. (ed.): Rome and Religion. A Cross-Disciplinary Dialogue on the Imperial Cult. Atlanta 2011, 49-59, here 49-53; BEARD-NORTH-PRICE (n. 54) 167-168. It is worth noting that such practices were already done in Italy. The only priests body, which cooperated per tota Italia was viri sacris faciundis college being associated later with Sibyl: GILLMEISTER: The Role (n. 17) 65-68.

${ }^{66}$ Cf. SOMMER, M.: Colonies - Colonisation - Colonialism: A Typological Reappraisal. AWE 10 (2011) 183-193, here 183-185.

${ }^{67}$ SANTI, C.: Jowisz w religii obywatelskiej starożytnego Rzymu [Jupiter in the Civic Religion of Archaic Rome]. Klio. Czasopismo poświęcone dziejom Polski i powszechnym 14 (2010) 33-47, here 33. 